Vol 13, Issue 10, 2020

\title{
ANTI-INFLAMMATORY ACTIVITY AND PHYTOCHEMISTRY OF EXTRACTS FROM THE ROOT BARK OF CALOTROPIS PROCERA (AIT.) R. BR. HEPATOPROTECTIVE MEDICINAL PLANT FROM BURKINA FASO
}

\author{
ERNEST NOGMA SOMBIÉ*, NOUFOU OUÉDRAOGO, ADAMA HILOU \\ Laboratoire de Biochimie et de Chimie Appliquée (LABIOCA), Université Joseph Ki-Zerbo, 03 BP 848 Ouagadougou 03, Burkina Faso. \\ Email: ernestsombie@yahoo.fr
}

Received: 30 June 2020, Revised and Accepted: 05 September 2020

ABSTRACT

Objective: This study aimed to assess the anti-inflammatory and antioxidant properties in vitro of Calotropis procera root bark.

Methods: Anti-inflammatory activities of the ethanolic extract of root bark of $C$. procera and its fractions were evaluated on lipoxygenase and xanthine oxidase (XO). Antioxidant activity was evaluated by trapping the 2,2-diphenylpicrylhydrazyl (DPPH) radical, hydrogen peroxide $\left(\mathrm{H}_{2} \mathrm{O}_{2}\right)$, by the reducing power ferric reducing antioxidant power. Inhibitory powers of lipid peroxidation and of degradation of D-deoxyribose as well as the contents of phenolic and triterpene compounds were also evaluated.

Results: Ethanolic extract showed interesting anti-inflammatory and antioxidant activities. Butanol fraction which is one of richest fractions for flavonoids (17.38 $\pm 0.13 \mathrm{mg}$ EQ/10 g extracts) showed the best percentages for inhibitions of XO (60.14 $\pm 4.89 \%$ ), degradation of D-deoxyribose $(81.04 \pm 0.77 \%)$, and the DPPH radical $(71.43 \pm 6.35 \%)$. Dichloromethane fraction which is the richest in triterpenes (1067.02 \pm 5.77 mg UAE/g extracts) showed the best percentages for inhibitions of lipoxygenase (56.45 $\pm 1.15 \%)$ and of lipid peroxidation (82.45 $\pm 0.73 \%)$. Ethyl acetate and residual aqueous fractions, respectively, showed the best activities of inhibiting $\mathrm{H}_{2} \mathrm{O}_{2}(75.38 \pm 0.76 \%)$ and for iron-reducing capacity (23.51 \pm 1.69 mg EAA/g extracts).

Conclusion: Ethanolic extract from C. procera root bark and its fractions, their particular the butanol and dichloromethane one, has anti-inflammatory and antioxidant properties which could prevent or attenuate liver injury and its complications.

Keywords: Calotropis procera, Anti-inflammatory, Antioxidant activities.

(C) 2020 The Authors. Published by Innovare Academic Sciences Pvt Ltd. This is an open access article under the CC BY license (http://creativecommons. org/licenses/by/4. 0/) DOI: http://dx.doi.org/10.22159/ajpcr.2020.v13i10.39275

\section{INTRODUCTION}

Hepatitis is liver inflammation that is a public health problem today [1]. According to the WHO [2] global report, more than 2 billion people were exposed to the hepatitis B virus (HBV) and 257 million people, or $3.5 \%$ of the population, had a chronic infection in 2015. Each year there are more than 4 million acute clinical cases of HBV infection. It is estimated that hepatitis $\mathrm{B}$ and its complications kill 1 million people each year. In Africa, HBV and hepatitis C virus are responsible for $80 \%$ of cirrhosis and hepatocellular carcinoma [3]. Over $80 \%$ of liver cancers occur in developing countries, in sub-Saharan Africa and in East and Southeast Asia. The incidence is much lower in developed countries [4]. In Burkina Faso, the prevalence of hepatitis B is estimated at around 9.41\% [5] and that of hepatitis C at around 2.14\% [6]. Aflatoxins including aflatoxin B1, excessive consumption of alcohol and tobacco, are also important risk factors for hepatitis and liver cancer. Oxidative stress is one of the factors involved in all liver diseases. In mammals, a sophisticated antioxidant system has been developed to maintain the redox homeostasis in the liver. When the reactive oxygen species (ROS) is excessive, the homeostasis will be disturbed, resulting in oxidative stress, which plays a critical role in liver diseases and other chronic and degenerative disorders [7,8]. In liver, oxidative stress stimulates transcription of pro-inflammatory factors, including nuclear factor kappa B, which is responsible for release of many inflammation mediators, interleukin-6 (IL-6), tumor necrosis factor $\alpha$ (TNF- $\alpha$ ), and IL-8 [9], which trigger various liver diseases, such as chronic viral hepatitis, alcoholic hepatitis, non-alcoholic steatosis, and their progression to hepatic fibrosis by collagen formation, cirrhosis, and liver cancer [7]. Medicinal plants are today an undeniable and invaluable source of antioxidant compounds which are used in the treatment of many pathologies including those caused by oxidative stress, inflammatory diseases such as hepatitis.

In Burkina Faso, traditional medicine remains the main health system for a large majority of the populations (70\%) not only because it constitutes an important element of their cultural heritage but also because of the means financial constraints for conventional medical system $[10,11]$. To justify and promote phytotherapy for the treatment of liver diseases, it seems imperative to investigate natural antiinflammatory and antioxidant natural products which could increase and improve the therapeutic arsenal for the care of liver diseases. Calotropis procera (Ait.) R. Br. (Apocynaceae) is a medicinal plant used in Burkina Faso in the treatment of infections including hepatitis, sickle cell crises, respiratory, and skin disorders $[12,13]$. Powder from dried root is used in the treatment of bronchitis, asthma, leprosy, eczema, elephantiasis, liver, and spleen diseases [14]. The aim of this study was to evaluate the anti-inflammatory and in vitro antioxidant activities of the root bark extracts of $C$. procera.

\section{METHODS}

\section{Plant material}

C. procera (Ait.) R. Br. root barks were harvested in Ouagadougou $\left(12^{\circ} 25^{\prime} 28.2^{\prime \prime} \mathrm{N} ; 1^{\circ} 28^{\prime} 0.06^{\prime \prime} \mathrm{W}\right)$ in August 2015 then dried out of the sun and pulverized to a fine powder by a blade mill (Gladiator Est., 1931 Type BN 1 Mach 40461 1083). Species was identified by Professor AmadéOuédraogo, Botanist at the UFR/SVT of Joseph Ki-Zerbo University. A specimen of this species was deposited at the Joseph KiZerbo University Herbarium under identification code ID-17033. 


\section{Extract preparation}

C. procera root bark powder $(50 \mathrm{~g})$ was placed in a dry jar and then $500 \mathrm{ml}$ of ethanol (96\%) was added. The mixture was subjected to mechanical stirring for $24 \mathrm{~h}$ at room laboratory temperature. The mixture was then filtered and the extract obtained was concentrated using a rotavapor equipped with a vacuum pump then ventilated dry in an oven at $40^{\circ} \mathrm{C}$ for $48 \mathrm{~h}$ before being stored in the refrigerator at $4^{\circ} \mathrm{C}$.

\section{Fractionation}

Ethanolic extract was fractionated using a separatory funnel using a series of solvents with increasing polarity hexane, dichloromethane, ethyl acetate, and butanol to obtain their respective fractions as well as the residual aqueous fraction.

\section{Phytochemistry study \\ Total polyphenol content determination}

Total phenolic compounds were determined using the Folin-Ciocalteu reagent (FCR) [15]. The reaction mixture was constituted of $25 \mu \mathrm{l}$ of extract (dissolved in pure methanol at a concentration of $1 \mathrm{mg} / \mathrm{ml}$ ) and $125 \mu \mathrm{l}$ of the FCR solution ( $0.2 \mathrm{~N}$ ). This mixture was incubated for $5 \mathrm{~min}$ and then $100 \mu \mathrm{l}$ of sodium carbonate solution ( $75 \mathrm{~g} / \mathrm{l}$ ) was added. The different solutions were left to stand in the dark for $1 \mathrm{~h}$. The reading was taken with a spectrophotometer (Epoch 251465, BioTek Instruments, U.S.A.) against a standard curve of gallic acid ( $y=0.0249 x ; R 2=0.99$ ) at $760 \mathrm{~nm}$. Analyzes were carried out in triples for each extract and the averages were calculated. The results were expressed in milligrams of gallic acid equivalent per gram of extract (mg EAG/g of extract).

\section{Total flavonoids content determination}

Total flavonoids were determined using aluminum trichloride [16] (Lamien-Meda et al., 2008). The reaction mixture was constituted of $100 \mu \mathrm{l}$ of aluminum trichloride $\left(2 \% \mathrm{AlCl}_{3}\right.$ in pure methanol) mixed with an equal volume of extract (dissolved in methanol at a concentration of $1 \mathrm{mg} / \mathrm{ml}$ ). A blank consisting of $100 \mu \mathrm{l}$ of extract and the same volume of methanol was produced. The absorbances were read 15 min later with a spectrophotometer (Epoch 251465, BioTek Instruments, U.S.A.) against a quercetin standard curve $\left(y=0.0289 x+0.0036 ; R^{2}=0.99\right)$. Analyzes were carried out in triples for each extract and the averages were calculated. The results were expressed in milligrams quercetin equivalent per gram of extract (mg EQ/g of extract).

\section{Total triterpenes content determination}

The total triterpenes were determined according to the colorimetric method described by Chang et al. [17]. The reaction mixture was composed of $100 \mu \mathrm{l}$ of extract (dissolved in methanol at $10 \mathrm{mg} / \mathrm{ml}$ ), $150 \mu \mathrm{l}$ of the solution of vanillin acetic-glacial acid (5\%), and $500 \mu \mathrm{l}$ of perchloric acid. The mixture was placed in a water bath at $60^{\circ} \mathrm{C}$ for $45 \mathrm{~min}$. The mixture was then cooled in an ice bath and then $2.25 \mathrm{ml}$ of glacial acetic acid was added. The absorbance was read by a spectrophotometer (Epoch 251465, BioTek Instruments, U.S.A.) at $548 \mathrm{~nm}$ against a standard curve of ursolic acid $\left(0.2139 x+0.0083 ; R^{2}=0,99\right)$. Averages of analyzes performed in triplicate for each extract were expressed in milligrams of ursolic acid equivalent per gram of extract (mg UAE/g of extract).

\section{Anti-inflammatory activity}

Lipoxygenase inhibitory activity

The inhibitory activity of extracts on the lipoxygenase was determined by the spectrophotometric method developed by Malterud et al. [18] with slight modifications. Briefly, the reaction medium consisted of a mixture of $100 \mu \mathrm{l}$ of extract prepared in the borate-methanol buffer (1\%) and $400 \mu \mathrm{l}$ of lipoxygenase $\left(167 \mathrm{U} \mathrm{ml}^{-1}\right)$. The mixture was incubated at room temperature for $2 \mathrm{~min}$ and the reaction was initiated by adding $500 \mu \mathrm{l}$ of the substrate solution (linoleic acid, $250 \mu \mathrm{M}$ in borate buffer). The kinetics of the reaction was followed at $234 \mathrm{~nm}$ for $2 \mathrm{~min}$. The inhibitory activity, expressed as a percentage of lipoxygenase inhibition, was calculated as follows:

Inhibition percentage $(\%)=\left(1-\left(\mathrm{V}_{0}\right.\right.$ sample $) /\left(\mathrm{V}_{0}\right.$ control $\left.)\right) \times 100$
$\mathrm{V}_{0}$ control $=$ activity of the enzyme without inhibitor $(\Delta \mathrm{abs}$. With enzyme $-\Delta$ abs. Without enzyme)

$\mathrm{V}_{0}$ sample $=$ activity of the enzyme with inhibitor ( $\Delta \mathrm{abs}$. With enzyme - $\Delta$ abs. Without enzyme)

\section{Xanthine oxidase (XO) inhibitory activity}

The inhibitory activity of the extracts on XO (EC.1.1.3.22) was evaluated according to the method described by Filha et al. [19] with slight modifications. The reaction mixture consisted of $50 \mu \mathrm{l}$ of extract at the final concentration of $100 \mu \mathrm{g} / \mathrm{ml}, 150 \mu \mathrm{l}$ of phosphate buffer $(\mathrm{pH}$ $7.5,1 / 15 \mathrm{M})$, and $50 \mu \mathrm{l}$ of enzyme solution $(0.28 \mathrm{U} / \mathrm{ml}$ prepared in the buffer). After pre-incubation of the mixture at $25^{\circ} \mathrm{C}$ for $1 \mathrm{~min}$, the reaction is initiated by adding $250 \mu \mathrm{l}$ of a substrate solution $(0.6 \mathrm{mM})$ and the absorbance was measured for $3 \mathrm{~min}$. A blank without extract was prepared. The analyzes were carried out in triplicate. Quercetin and gallic acid were used as positive controls. The inhibiting activity of $\mathrm{XO}$, expressed as a percentage of inhibition, was calculated using the formula below:

$$
\text { Inhibition percentage }(\%)=\left(1-\mathrm{V} / \mathrm{V}_{0}\right) \times 100
$$

$\mathrm{V}_{0}$ : Variation of the absorbance per minute of the test without the extract; V: Variation of the absorbance per minute of the test with the extract.

\section{Lipid peroxidation inhibitory activity and cellular DNA structure} protection test

\section{Lipid peroxidation inhibitory activity}

The lipid peroxidation inhibitory activity of the extract was determined by the method of 2-thiobarbituric acid (TBA) described by Sombié et al. [20]. In this method, $0.2 \mathrm{ml}$ of extract ( $1 \mathrm{mg} / \mathrm{mL}$ ) was mixed with $1 \mathrm{~mL}$ liver homogenate $(10 \%, \mathrm{v} / \mathrm{v})$ in Tris- $\mathrm{HCl}$ buffer $(50 \mu \mathrm{M}, \mathrm{pH}$ $7.40)$, then $50 \mu \mathrm{l}$ of $\mathrm{FeCl}_{2}(0.5 \mathrm{mM})$ and $50 \mu \mathrm{l}$ of $\mathrm{H}_{2} \mathrm{O}_{2}(0.5 \mathrm{mM})$ were added. The mixture was incubated at $37^{\circ} \mathrm{C}$ for $60 \mathrm{~min}$, then $1 \mathrm{~mL}$ of trichloroacetic acid (TCA) (15\%) and $1 \mathrm{~mL}$ of 2 -TBA $(0.67 \%)$ were added. The mixture was then heated in boiling water for $15 \mathrm{~min}$. The absorbance was read at $532 \mathrm{~nm}$ at the spectrophotometer against a blank. Quercetin and gallic acid were used as the reference compound. The results were expressed as percentage inhibition.

Cell DNA structure protection test: D-deoxyribose degradation inhibitory activity

The inhibitory activity of the deoxyribose degradation was determined by the method described by Perjési and Rozmer [21]. The reaction mixture consisted of $100 \mu \mathrm{l}$ of extract (in $50 \mathrm{mM}$ phosphate buffer, $\mathrm{pH}$ 7.4), $100 \mu \mathrm{l}$ of ethylenediaminetetraacetic acid (1.04 mM aqueous), $100 \mu \mathrm{l}$ of iron sulfate (100 mM aqueous), $100 \mu \mathrm{l}$ of deoxyribose ( $60 \mathrm{mM}$ aqueous), and $100 \mu \mathrm{l}$ of hydrogen peroxide $\left(\mathrm{H}_{2} \mathrm{O}_{2}\right)(10 \mathrm{mM})$. The volume was made up to $1 \mathrm{ml}$ with phosphate buffer, then the mixture was incubated (at $37^{\circ} \mathrm{C}$ for $\left.1 \mathrm{~h}\right)$. TCA ( $1 \mathrm{ml}, 15 \%$ aqueous) and TBA ( $1 \mathrm{ml}, 0.675 \%$ in $25 \mathrm{mM}$ aqueous $\mathrm{NaOH}$ ) were added, then the whole was put back to incubation $\left(100^{\circ} \mathrm{C}\right.$ for $\left.15 \mathrm{~min}\right)$. After cooling in an ice bath ( $5 \mathrm{~min}$ ), the tubes were centrifuged ( $3000 \mathrm{rpm}$ for $10 \mathrm{~min}$ ), then $200 \mu \mathrm{l}$ of the supernatant were transferred to 96-well microplates. The trapping of deoxyribose degradation was measured using a spectrophotometer at $532 \mathrm{~nm}$ against a blank. Gallic acid and quercetin were used as the reference substance. The experiment was carried out in triplicate and the activity of the extract to trap the degradation of deoxyribose was expressed as a percentage of trapping the degradation of deoxyribose compared to the control without extract.

\section{Antioxidant activities}

\section{2,2-diphenylpicrylhydrazyl (DPPH) free radical scavenging activity}

Antioxidant activity DPPH was carried out according to the method described by Velazquez et al. [22]. This method was based on the reduction in absorbance at $517 \mathrm{~nm}$ of the stable free radical DPPH, in the presence of a hydrogen radical donor. Three tests were carried out by mixing $100 \mu \mathrm{l}$ of sample $(1 \mathrm{mg} / \mathrm{ml})$ dissolved in methanol and 
$200 \mu \mathrm{l}$ of DPPH. After 15 min of incubation, the absorbance was read at $517 \mathrm{~nm}$ against a blank (100 $\mu \mathrm{l}$ of methanol and $200 \mu \mathrm{l}$ of DPPH) using a spectrophotometer. The antiradical activity was expressed as a percentage of inhibition of DPPH. Gallic acid and quercetin were used as references.

\section{$\mathrm{H}_{2} \mathrm{O}_{2}$ scavenging activity}

The ability of the extracts to scavenge $\mathrm{H}_{2} \mathrm{O}_{2}$ was assessed by Mohan et al. [23]. The reaction mixture consisting of $100 \mu \mathrm{l}$ of extract $(1 \mathrm{mg} / \mathrm{ml}$ in $10 \mathrm{mM}$ phosphate buffer, $\mathrm{pH} 7.4)$ and $100 \mu \mathrm{l}$ of $\mathrm{H}_{2} \mathrm{O}_{2}(100 \mathrm{mM})$ was incubated for $10 \mathrm{~min}$ at room temperature. The residual $\mathrm{H}_{2} \mathrm{O}_{2}$ was measured at $230 \mathrm{~nm}$ with the spectrophotometer against a blank containing only the phosphate buffer. The activity of the $\mathrm{H}_{2} \mathrm{O}_{2}$ scavenger extract was expressed as percent $\mathrm{H}_{2} \mathrm{O}_{2}$ scavenging (\% inhibition) relative to control without extract. The experiment was carried out in triplicate and gallic acid and quercetin were used as a reference substance.

\section{Ferric reducing antioxidant power (FRAP) assay}

FRAP was evaluated according to the method described by Hinneburg et al. [24]. In a test tube containing $0.5 \mathrm{~mL}$ of extract $(1 \mathrm{mg} / \mathrm{ml})$ to be tested, $1.25 \mathrm{ml}$ of phosphate buffer $(0.2 \mathrm{M}, \mathrm{pH} 6.6)$ and $1.25 \mathrm{ml}$ of potassium were added hexacyanoferrate ( $1 \%$ aqueous). The mixture was heated at $50^{\circ} \mathrm{C}$ in a water bath for $30 \mathrm{~min}$. After cooling, TCA $(1.25 \mathrm{ml}, 10 \%)$ was added and the mixture was then centrifuged (2000 rpm for $10 \mathrm{~min})$. Three aliquots $(125 \mu \mathrm{l})$ of the supernatant were transferred into a 96-well microplate to which $125 \mu \mathrm{l}$ of distilled water and then $25 \mu \mathrm{l}$ of $\mathrm{FeCl}_{3}(0.1 \%$ aqueous $)$ were added. The evaluation of the reducing power was carried out at $700 \mathrm{~nm}$ with spectrophotometer against a standard curve of ascorbic acid. The results are expressed in milligram equivalent ascorbic acid per gram of extract (mg EAA/g extract).

\section{Statistical analysis}

Statistical analysis was carried out with GraphPad Prism software (version 5.0) and MS Excel software was used to obtain the ascorbic acid standard curve and the correlation curve as well as the inhibition percentages, the means and the deviations standards. ANOVA one way followed by the Bonferroni test was used to measure the degree of statistical significance of the results. A significant difference is considered for $\mathrm{p}<0.05$.

\section{RESULTS}

Total phenolic and triterpenes content

Phytochemistry study has shown that ethanolic extract is rich in total triterpenes $(1045.99 \pm 16.14 \mathrm{mg} \mathrm{UAE} / \mathrm{g})$ than total phenolics $(33.47 \pm 3.59 \mathrm{mg} E A G / \mathrm{g})$ and flavonoids $(01.36 \pm 0.17 \mathrm{mg} \mathrm{EQ} / 10 \mathrm{~g}$ ) (Table 1). Dichloromethane fraction showed the best total triterpene content (1067.02 $\pm 5.77 \mathrm{mg} \mathrm{UAE} / \mathrm{g})$ and ethyl acetate fraction showed the best total polyphenol content $(50.01 \pm 1.41 \mathrm{mg}$ EAG/g). Residual aqueous fractions $(21.98 \pm 0.54 \mathrm{mg} E Q / 10 \mathrm{~g})$ and butanol (17.38 $\pm 0.13 \mathrm{mg} \mathrm{EQ} / 10 \mathrm{~g})$ are the richest in flavonoids.

\section{Anti-inflammatory activities}

Extracts anti-inflammatory activity in vitro were evaluated on lipoxygenase and XO (Table 2). Crude ethanolic extract, hexane, and dichloromethane fractions showed the best lipoxygenase inhibitory activities with a percentage inhibition greater than $50 \%$ and statistically equal to that of quercetin but lower than that of gallic acid, used as reference substance. Other extracts showed lipoxygenase inhibitory activities of $<50 \%$. Butanolic, dichloromethane, ethyl acetate fractions, and crude ethanolic extract showed percentage inhibitions of XO greater than $50 \%$. The best percentage inhibition of XO was obtained with butanol fraction $(60.14 \pm 4.89 \%)$ which is statistically equal to that of quercetin $(62.22 \pm 3.06 \%)$ but lower than that gallic acid $(88.76 \pm 3.19 \%)$.

\section{Lipid peroxidation inhibitory activity and cellular DNA structure protection test in vitro}

Table 3 shows the capacity of the extracts effect against lipoperoxidation and degradation of deoxyribose. All extracts, except the hexane fraction, showed percentages of inhibition of lipid peroxidation and degradation of D-deoxyribose greater than $50 \%$. The dichloromethane fraction showed the best percentage inhibition of lipid peroxidation $(82.45 \pm 0.73 \%)$ which is statistically lower than that of gallic acid $(91.70 \pm 1.55 \%)$ and quercetin $(90.59 \pm 0.99 \%)$. The residual aqueous $(84.43 \pm 0.77 \%)$ and butanolic $(81.04 \pm 0.77 \%)$ fractions showed the best inhibitory activities against deoxyribose degradation $(84.43 \pm 0.77 \%)$

Table 1: Content of phenolic compounds and triterpenes

\begin{tabular}{llll}
\hline Extracts & \multicolumn{2}{l}{ Phytochemistry } & \multicolumn{1}{c}{ Total triterpenes content } \\
& (mg EAU/g) \\
\cline { 2 - 4 } & $\begin{array}{l}\text { Total phenolic content } \\
\text { (mg EAG/g) }\end{array}$ & $\begin{array}{l}\text { Total flavonoids } \\
\text { content (mg EQ/10 g) }\end{array}$ & $1045.99 \pm 16.14^{\mathrm{a}}$ \\
\hline Ethanolic extract & $33.47 \pm 3.59^{\mathrm{b}}$ & $01.36 \pm 0.17^{\mathrm{d}}$ & $890.77 \pm 16.25^{\mathrm{b}}$ \\
Hexane fraction & $15.33 \pm 1.01^{\mathrm{d}}$ & $03.66 \pm 0.29^{\mathrm{d}}$ & $1067.02 \pm 5.77^{\mathrm{a}}$ \\
DCM fraction & $19.02 \pm 0.43^{\mathrm{d}}$ & $10.61 \pm 0.91^{\mathrm{c}}$ & $312.62 \pm 10.69^{\mathrm{c}}$ \\
Ethyl acetate fraction & $50.01 \pm 1.41^{\mathrm{a}}$ & $09.76 \pm 2.14^{\mathrm{c}}$ & $205.09 \pm 7.97^{\mathrm{d}}$ \\
Butanol fraction & $28.33 \pm 2.27^{\mathrm{c}}$ & $17.38 \pm 0.13^{\mathrm{b}}$ & $24.87 \pm 0.33^{\mathrm{e}}$ \\
\hline Residual aqueous fraction & $33.21 \pm 1.73^{\mathrm{b}}$ & $21.98 \pm 0.54^{\mathrm{a}}$ & \\
\hline
\end{tabular}

mg EAG/1 g: Milligrams gallic acid equivalent per $1 \mathrm{~g}$ of dry extract; $\mathrm{mg}$ EQ/10 g: Milligrams quercetin equivalent per $10 \mathrm{~g}$ of dry extract; $\mathrm{mg}$ EAU/1 g: Milligrams ursolic acid equivalent per $1 \mathrm{~g}$ of dry extract; each value represents mean \pm SEM; the difference is significant ( $p>0.05$ ) for letters (a to e)

Table 2: Results of anti-inflammatory activities in vitro

\begin{tabular}{lll}
\hline Extracts & Anti-inflammatory activities in vitro (at $\mathbf{1 0 0} \mathbf{\mu g} / \mathbf{m L})$ & \\
\cline { 2 - 3 } & Lipoxygenase inhibition (\%) & Xanthine oxidase inhibition (\%) \\
\hline Ethanolic extract & $61.91 \pm 4.30^{\mathrm{b}}$ & $53.04 \pm 2.47^{\mathrm{c}}$ \\
Hexane fraction & $56.15 \pm 12.16^{\mathrm{b}}$ & $42.60 \pm 3.63^{\mathrm{d}}$ \\
DCM fraction & $56.45 \pm 1.15^{\mathrm{b}}$ & $57.24 \pm 3.54^{\mathrm{c}}$ \\
Ethyl acetate fraction & $41.14 \pm 0.14^{\mathrm{c}}$ & $54.65 \pm 3.18^{\mathrm{c}}$ \\
Butanol fraction & $48.53 \pm 2.27^{\mathrm{c}}$ & $60.14 \pm 4.89^{\mathrm{b}, \mathrm{c}}$ \\
Residual aqueous fraction & $44.52 \pm 4.97^{\mathrm{c}}$ & $38.40 \pm 5.94^{\mathrm{d}}$ \\
Gallic acid & $77.01 \pm 7.58^{\mathrm{a}}$ & $88.76 \pm 3.19^{\mathrm{a}}$ \\
Quercetin & $58.34 \pm 4.01^{\mathrm{b}}$ & $62.22 \pm 3.06^{\mathrm{b}}$ \\
\hline
\end{tabular}

Each value represents mean \pm SEM; the difference is significant $(p>0.05$ ) for letters (a to $d$ ) 
statistically lower than those of quercetin $(95.77 \pm 0.03 \%)$ and gallic acid $(87.99 \pm 0.07 \%)$ used as reference substances.

\section{Antioxidant activities in vitro}

Table 4 shows the inhibitory power of extracts of the DPPH radical by hydrogen transfer, the inhibitory power of $\mathrm{H}_{2} \mathrm{O}_{2}$, and the reducing power of ferric ion $\left(\mathrm{Fe}^{3+}\right)$ to ferrous ion $\left(\mathrm{Fe}^{2+}\right)$ of the extracts. The butanolic, ethyl acetate, and dichloromethane fractions showed percentage inhibitions of the DPPH radical greater than 50\% but statistically lower than those of the reference compounds, gallic acid, and quercetin. The ethyl acetate $(75.38 \pm 0.76 \%)$, butanolic $(54.69 \pm 3.00 \%)$, and dichloromethane $(50.18 \pm 1.79)$ fractions showed percentage inhibitions of $\mathrm{H}_{2} \mathrm{O}_{2}$ greater than or equal to $50 \%$ and statistically superior to that of the reference substances, gallic acid $(22.74 \pm 2.65 \%)$ and quercetin $(09.59 \pm 0.39 \%)$. The ethyl acetate fraction had the best percentage inhibition of $\mathrm{H}_{2} \mathrm{O}_{2}$. The residual aqueous fraction showed the best reducing power of ferric ion to ferrous ion $(23.51 \pm 1.69 \mathrm{mg} \mathrm{EAA} / \mathrm{g})$.

\section{DISCUSSION}

Lipoxygenases are enzymes that insert oxygen at positions 5, 12 , and 15 of arachidonic acid or linoleic acid, thus giving rise to hydroperoxides, hence, three different lipoxygenases in animals. 5-Lypoxygenase is an inflammatory enzyme located in nuclear membranes of liver cells (Kupffer cells, hepatocytes) which is involved in the pathogenesis of hepatocellular damage [25]. Studies have shown that during hepatic cirrhosis, there is an increase in 5-lipoxygenase expression and leukotriene formation in the liver [26]. 5-lypoxygenase produced plays an important role in the survival of Kupffer cells and in the pathogenesis of liver inflammation and hepatic fibrosis [27]. Inhibition of lipoxygenase, in particular 5-lipoxygenase, induces growth arrest and apoptosis of liver Kupffer cells, the activation of which generates the production of inflammatory mediators (IL6, TNF- $\alpha$, IL1, and IL-1 $\beta$ ) and fibrosis (TGF- $\beta$ ) [28]. Inhibition of 5-lipoxygenase expression pathway in liver attenuates the inflammation of liver by a decrease in production of pro-inflammatory cytokines [29] and promotes the modulation of mediator pro-collagens such as matrix metalloproteinase- 2 and tissue inhibitor of metalloproteinase-2 through the significant reduction of their activities [25]. Crude ethanolic extract, hexane, and dichloromethane fractions which are rich in triterpenes have shown the best lipoxygenase inhibiting activities, suggesting that the triterpenes could be responsible for this activity, as shown by the good correlation $\left(\mathrm{R}^{2}=0.79\right)$ obtained between triterpene contents and percentages of lipoxygenase inhibition. The inhibitory activity of extracts on the lipoxygenase could contribute to attenuate the inflammation of liver and thus to prevent installation or progression of hepatic fibrosis [28]. XO is preferred therapeutic target in treatment of gout, damage caused by oxidants, inflammation, and even cancer. It is considered an important source of production of superoxide anion $\left(\mathrm{O}_{2}^{-}\right)$. This superoxide anion and other ROS produced during XO activity contribute to ischemic damage through catabolism of adenosine triphosphate (ATP) during hypoxia and increase availability of electron acceptors (molecular oxygen) during reperfusion. In liver, these XO-derived ROS act as mediators of inflammatory signal transduction pathways and expression of pro-inflammatory genes [30]. XO inhibitors are said to have beneficial effects against ischemic damage to the liver, heart, kidney, brain, intestine, lung, and other tissues [30]. Extracts contain phenolic compounds known for their antioxidant power which are potential inhibitors of inflammatory enzymes such as cyclooxygenase, lipoxygenase, and XO [31]. However, phenolic compounds are not the only compounds responsible for anti-inflammatory activities, certain terpenoids, in particular triterpenes and triterpene saponins, also have anti-inflammatory activities against XO [32]. XO and lipoxygenase inhibitors could be a therapeutic mean in acute and chronic inflammation of liver and in many other liver diseases.

Lipid peroxidation is action of free radicals on membrane lipids which leads to release of lipid by-products including malondialdehyde (MDA) and 4-hydroxynonenal [33]. In vitro, ferrous ions released by iron dichloride react with $\mathrm{H}_{2} \mathrm{O}_{2}$ to form hydroxyl radicals according to Fenton reaction. These radicals attack lipid constituents of hepatocyte membranes causing their alteration with release of MDA which forms with thiobarbituric acid a red complex which absorbs at $560 \mathrm{~nm}$. Lipoperoxidation of membranes leads to a deterioration in their functionality. In vivo, lipid peroxidation of hepatocyte membranes is cause of acute and chronic inflammation of liver. All the extracts, except hexane fraction, significantly inhibit lipid peroxidation, thus preventing

Table 3: Lipid peroxidation inhibitory activity and cellular DNA structure test in vitro

\begin{tabular}{lll}
\hline \multirow{2}{*}{ Extracts } & \multicolumn{2}{l}{ Lipid peroxidation inhibitory activity and cellular DNA structure test in vitro } \\
\cline { 2 - 3 } & Lipid peroxidation inhibitory activity (\%) & D-deoxyribose degradation inhibitory activity (\%) \\
\hline Ethanolic extract & $59.33 \pm 0.95^{\mathrm{d}}$ & $68.36 \pm 0.77^{\mathrm{e}}$ \\
Hexane fraction & $13.23 \pm 1.81^{\mathrm{e}}$ & $12.69 \pm 0.50^{\mathrm{f}}$ \\
DCM fraction & $82.45 \pm 0.73^{\mathrm{b}}$ & $69.20 \pm 1.27^{\mathrm{e}}$ \\
Ethyl acetate fraction & $71.53 \pm 0.33^{\mathrm{c}}$ & $68.02 \pm 0.88^{\mathrm{e}}$ \\
Butanol fraction & $67.30 \pm 2.15^{\mathrm{c}}$ & $81.04 \pm 0.77^{\mathrm{c}, \mathrm{d}}$ \\
Residual aqueous fraction & $69.21 \pm 0.55^{\mathrm{c}}$ & $84.43 \pm 0.77^{\mathrm{c}}$ \\
Gallic acid & $91.70 \pm 1.55^{\mathrm{a}}$ & $87.99 \pm 0.07^{\mathrm{b}}$ \\
Quercetin & $90.59 \pm 0.99^{\mathrm{a}}$ & $95.77 \pm 0.03^{\mathrm{a}}$ \\
\hline
\end{tabular}

Each value represents mean \pm SEM; the difference is significant $(p>0.05$ ) for letters (a to $f$ )

Table 4: Antioxidant activities in vitro

\begin{tabular}{|c|c|c|c|}
\hline \multirow[t]{2}{*}{ Extracts } & \multicolumn{3}{|l|}{ Antioxidant activities in vitro } \\
\hline & DPPH free radical scavenging activity (\%) & $\mathrm{H}_{2} \mathrm{O}_{2}$ scavenging activity (\%) & FRAP (mg EAA/g of extract) \\
\hline Ethanolic extract & $30.47 \pm 1.86^{\mathrm{c}}$ & $35.82 \pm 1.04^{c}$ & $08.30 \pm 1.50^{c}$ \\
\hline Hexane fraction & $27.95 \pm 1.97^{c}$ & $36.71 \pm 4.09^{c}$ & $12.57 \pm 0.50^{\mathrm{b}}$ \\
\hline DCM fraction & $62.20 \pm 0.00^{\mathrm{b}}$ & $50.18 \pm 1.79^{b}$ & $07.67 \pm 1.23^{c}$ \\
\hline Ethyl acetate fraction & $68.49 \pm 1.24^{\mathrm{b}}$ & $75.38 \pm 0.76^{\mathrm{a}}$ & $14.82 \pm 2.50^{\mathrm{b}}$ \\
\hline Butanol fraction & $71.43 \pm 6.35^{\mathrm{b}}$ & $54.69 \pm 3.00^{\mathrm{b}}$ & $07.83 \pm 1.00^{c}$ \\
\hline Residual aqueous fraction & $32.39 \pm 6.21^{\mathrm{c}}$ & $20.26 \pm 1.46^{\mathrm{d}}$ & $23.51 \pm 1.69^{\mathrm{a}}$ \\
\hline Gallic acid & $81.77 \pm 0.18^{\mathrm{a}}$ & $22.74 \pm 2.65^{\mathrm{d}}$ & $\mathrm{Nd}$ \\
\hline Quercetin & $78.84 \pm 5.41^{\mathrm{a}}$ & $09.59 \pm 0.39^{\mathrm{e}}$ & $\mathrm{Nd}$ \\
\hline
\end{tabular}

mg EAA/g: Milligrams ascorbic acid equivalent per gram of dry extract, FRAP: Ferric reducing antioxidant power; DPPH: 2,2-diphenyl-1-picrylhydrazyl, $\mathrm{H}_{2} \mathrm{O}_{2}$ : Hydrogen peroxide; each value represents mean \pm SEM; the difference is significant $(p>0.05)$ for letters (a to e). Nd: Non-determined 
alteration of structure and function of hepatocyte membranes. Dichloromethane fraction which is rich in triterpenes has shown the best percentage of inhibition of lipid peroxidation, suggesting that these compounds could be responsible for its activity [34]. DNA, whether nuclear or mitochondrial, is also a major target for free radicals. The $\mathrm{O}_{2}{ }^{\bullet}$ and $\mathrm{OH}^{\bullet}$ radicals cause DNA damage. These can indeed interact with DNA deoxyribose but also with its purine and pyrimidine bases. These structural alterations when they are not "repaired" lead in the long term to genetic alterations: Chromosomal breaks, mutations, deletions, and amplifications, at the origin of a dysfunction in protein metabolism [9]. Extracts, in particular the residual aqueous and butanolic fractions which are richer in flavonoids, have shown good percentages of inhibition of degradation of D-deoxyribose suggesting their capacities to protect DNA structure of liver cells.

Oxidative stress, an imbalance between oxidants and antioxidants in favor of oxidants, is involved in pathogenesis of liver diseases, whatever their etiology and the course of disease [8]. ROS, precursors of oxidative stress, cause damage and necrosis of hepatocytes causing inflammation of liver. Due to their unstable nature, ROS are toxic and interact with a whole series of important biological substrates. Protein denaturation, enzyme inactivation, glucose oxidation, DNA breaks with the possibility of mutation, and lipid peroxidation processes can then appear with often irreversible consequences for the cell $[35,36] . \mathrm{H}_{2} \mathrm{O}_{2}$, a biological, non-radical ROS, can be formed in tissues by oxidative processes. The capacity of $\mathrm{H}_{2} \mathrm{O}_{2}$ trapping shows that the extracts have the capacity to prevent the Fenton reaction which is at origin of formation of hydroxyl radical [37]. These extracts could, therefore, protect structures and functions of cell membranes as well as structure of DNA which are preferred targets of hydroxyl radicals. They, therefore, contain antioxidant compounds which could protect hepatocytes against effect of oxidative stress. DPPH radical inhibition shows that extracts have the capacity to transfer an electron to this radical to neutralize it, suggesting their antioxidant activity [38]. FRAP test shows ability of the extracts to give an electron to the ferric ion $\mathrm{Fe}^{3+}$ to reduce it to the ferrous ion $\mathrm{Fe}^{2+}[10]$. This reflects the reducing power of extracts, in particular that of residual aqueous fraction which is richer in phenolic compounds and in flavonoids. The extracts could serve as inhibitors or scavengers of free radicals, possibly acting as primary antioxidants [39]. C. procera root bark, therefore, has antioxidant activities [40].

\section{CONCLUSION}

The data obtained from this study have evidenced that the ethanolic extract from root bark of $C$. procera and also its fractions has antiinflammatory and antioxidant activities which can explain the hepatoprotective use of this medicinal plant. These properties could be due to the phenolic and triterpene compounds that they contain. The butanol and dichloromethane fractions have exhibited the best antioxidant and anti-inflammatory activities.

These results thus gathered constitute a contribution in the justification of traditional use of this plant in the treatment of liver diseases; and so, the root barks of $C$. procera could be a resource for formulating phytomedicines for treating inflammation of liver and its complications.

\section{ACKNOWLEDGMENTS}

We would like to thank Prof. Martin Kiendrebéogo (Director of LABIOCA), Prof. Sylvain Ouédraogo (Director of IRSS), and Dr. Félix Kini (Head of the MEPHATRA-PH department) who offered us the technical platform for this work.

\section{AUTHORS' CONTRIBUTIONS}

Ernest Nogma Sombié carried out the various tests as well as the statistical analysis. The work was supervised by Dr. Noufou Ouédraogo and Prof. Adama Hilou. Finally, the writing of the manuscript was done by Ernest Nogma Sombié, Dr. Noufou Ouédraogo, and Prof. Adama Hilou.

\section{COMPETING INTEREST}

The authors declare that they have no competing interest.

\section{AUTHORS' FUNDING}

Funds for the present study were provided by FONRID (fonds national de la recherchescientifiqueet de l'innovation pour le développement) in Burkina Faso.

\section{REFERENCES}

1. Meryem J, Bisma R, Harunor R, Thao L, Shafquat R. Update on global epidemiology of viral hepatitis and preventive strategies. World J Clin Cases 2018;6:589-99.

2. World Health Organization. Global Hepatitis Report. Geneva: World Health Organization; 2017

3. Lemoine M, Eholié S, Lacombe K. Reducing the neglected burden of viral hepatitis in Africa: Strategies for a global approach. J Hepatol 2015;62:469-76.

4. Organisation Mondiale de la Santé. Hépatite Virale, Soixantesixième Session Guam, Comité Régional WPR/RC66/4. États-Unis d'Amérique: Organisation Mondiale de la Santé; 2015.

5. Lingani M, Akita T, Ouoba S, Sanou AM, Sugiyama A, Tarnagda Z, et al. High prevalence of hepatitis B infections in Burkina Faso (19962017): A systematic review with meta-analysis of epidemiological studies. BMC Public Health 2018;18:551

6. Traoré KA, Rouamba SH, Traoré AS, Roques P, Barro N. Viral hepatitis in west African country, Burkina Faso. Adv Trop Med Public Health Int 2015;5:90-106.

7. Li S, Tan HY, Wang N, Zhang ZJ, Lao L, Wong CW, et al. The role of oxidative stress and antioxidants in liver diseases. Int J Mol Sci 2015;16:26087-124.

8. Kívia QA, Fabiana AM, John MS, Orlando RP, Juliana CF, Marília OF, Oxidative stress and inflammation in hepatic diseases: Therapeutic possibilities of N-acetylcysteine. Int J Mol Sci 2015;16:30269-308.

9. Koechlin-Ramonatxo C. Oxygène, stress oxydant et supplémentations antioxydantes ou un aspect différent de la nutrition dans les maladies respiratoires. Nutr Clin Métabol 2006;20:165-77.

10. Ladoh YC, Dibong SD, Nyegue MA, Djembissi TR, Lenta NB, Mpondo ME, et al. Activité antioxydante des extraits méthanoliques de Phragmanthera capitata (Loranthaceae) récoltée sur Citrus sinensis. J Appl Biosci 2014;84:7636-43

11. Kone D. Enquête Ethnobotanique de Six Plantes Médicinales Maliennes-extraction, Identification D'alcaloïdes-caractérisation, Quantification de Polyphénols: Etude de Leur Activité Antioxydante, Thèse de Doctorat en Chimie Organique. France, Bamako: Universités Paul Verlaine de Metz-UPV-M; 2009. p. 157.

12. Sourabie TS, Kinda D, Yaro B, Nikiema JB. Ethnobotanical survey of medicinal plants used by the traditional medical healers in the villages of Bérégadougou and Fabédougou (Cascades region, Burkina Faso)-Balanites aegyptiaca balanitaceae tree fruit. IOSR J Pharm 2013;3:38-45

13. Zerbo P, Millogo-Rasolodimby J, Nacoulma-Ouedraogo OG, Damme PV. Plantes médicinales et pratiques médicales au Burkina Faso: Cas des Sanan. Bois For Trop 2011;307:a20481

14. Upadhyay RK. Ethnomedicinal, pharmaceutical and pesticidal uses of Calotropis procera (Aiton) (Family: Asclepiadaceae). Int J Green Pharm 2014;8:135-46.

15. Singleton VL, Orthofer R, Lamuela-Raventós RM. Analysis of total phenols and other oxidation substrates and antioxidants by means of folin-ciocalteu reagent. Methods Enzymol 1999;299:152-78.

16. Lamien-Meda A, Lamien CE, Compaoré MM, Kiendrebeogo M, Zeba B, Millogo JF, et al. Polyphenol content and antioxidant activity of fourteen wild edible fruits from Burkina Faso. Molecules 2008;13:581-94.

17. Chang CL, Lin CS, Lai GH. Phytochemical characteristics, free radical scavenging activities, and neuroprotection of fivemedicinal plant extracts. Evid Based Complement Alternat Med 2012;2012:8.

18. Malterud KE, Rydland KM. Inhibitors of 15-lipoxygenase from orange peel. J Agric Food Chem 2000;48:5576-80.

19. Filha FZ, Vitolo LG, Fietto JA, Saude-Guimaraes DA. Xanthine oxidase inhibitory activity of Lychnophora species from Brazil (Arnica). J Ethnopharmacol 2006;107:79-82

20. Sombié PE, Hilou A, Coulibaly AY, Tibiri A, Kiendrebeogo M, Nacoulma OG. Brain protective and erythrocytes hemolysis inhibition potencials from galls of Guiera senegalensis Gmel (Combretaceae). J 
Pharmacol Toxicol 2011;6:361-70.

21. Perjési P, Rozmer Z. Kinetic analysis of some chalcones and synthetic chalcone analogues on the fenton-reaction initiated deoxyribose degradation assay. Open Med Chem J 2011;5:61-7.

22. Velazquez E, Tournier HA, Mordiyavich-Buschiazza P, Saavedra G, Schinnella GR. Antioxydant activity of Paraguayan plants extracts. Fitoterapia 2003;74:91-7.

23. Mohan SC, Balamurugan V, Salini ST, Rekha R. Metal ion chelating activity and hydrogen peroxide scavenging activity of medicinal plant Kalanchoe pinnata. J Chem Pharm Res 2012;4:197-202.

24. Hinneburg I, Damien DH, Hiltunen R. Antioxidant activities of extracts from selected culinary herbs and spices. Food Chem 2006;97:122-9.

25. Titos E, Claria J, Planaguma A, Lopez-Parra M, Gonzalez-Periz A, Gaya J, et al. Inhibition of 5-lipoxygenase-activating protein abrogates experimental liver injury: Role of kupffer cells. J Leukocyte Biol 2005;78:1204747.

26. Titos E, Clària $\mathrm{J}$, Bataller $\mathrm{R}$, Bosch-Marcé $\mathrm{M}$, Ginès $\mathrm{P}$, Jiménez W, et al. Hepatocyte-derived cysteinyl-leukotrienes modulate vascular tone in experimental cirrhosis. Gastroenterology 2000;119:794-805

27. Titos E, Planagumà A, López-Parra $M$, Villamor $\mathrm{N}$, Miquel R, Jiménez W, et al. 5-Lipoxygenase (5-LO) is involved in kupffer cell survival. Possible role of 5-LO products in the pathogenesis of liver fibrosis. Comparative Hepatol 2004;3:S19.

28. Titos E, Claria J, Planaguma A, Lopez-Parra M, Villamor N, Parrizas M, et al. Inhibition of 5-lipoxygenase induces cell growth arrest and apoptosis in rat kupffer cells: Implications for liver fibrosis. FASEB J 2003;17:1745-7.

29. Li L, Liu YR, Gao S, Li JF, Li SS, Zhang DD, et al. Inhibition of 5-lipoxygenase pathway attenuates acute liver failure by inhibiting macrophage activation. J Immunol Res 2014;2014:9.

30. Pacher P, Nivorozhkin A, Szabó C. Therapeutic effects of xanthine oxidase inhibitors: Renaissance half a century after the discovery of allopurinol. Pharmacol Rev 2006;58:87-114

31. Nile SH, Ko EY, Kim DH, Keum YS. Screening of ferulic acid related compounds as inhibitors of xanthine oxidase and cyclooxygenase-2 with anti-inflammatory activity. Rev Brasil Farmacogn 2016;26:50-5.

32. Lin KW, Huang AM, Tu HY, Lee LY, Wu CC, Hour TC, et al. Xanthine oxidase inhibitory triterpenoid and phloroglucinol from guttiferaceous plants inhibit growth and induced apoptosis in human NTUB1 cells through a ROS-dependent mechanism. J Agricu Food Chem 2011;59:407-14.

33. Cillard J, Cillard P. Mécanismes de la peroxydation lipidique et des anti-oxydations. OCL 2006;13:24-9.

34. Santiago LA, Dayrit KC, Correa PC, Mayor AB. Comparison of antioxidant and free radical scavenging activity of triterpenes $\alpha$-amyrin, oleanolic acid and ursolic acid. J Natl Prod 2014;7:29-36.

35. Pincemail J, Bonjean K, Cayeux K, Defraigne JO. Mécanismes physiologiques de la defenseantioxydante. Nutr Clin Metabol 2002;16:233-9.

36. Balakrishnan BB, Krishnasamy K. Evaluation of free radical screening and antioxidant potential of Moringa concanensis nimmo-a medicinal plant used in Indian traditional medication system. Int J Pharm Pharm Sci 2018;10:91-7.

37. Habibur R, Manjula K, Anoosha T, Nagaveni KM, Chinna E, Dipankar B. In vitro anti-oxidant activity of Citrullus lanatus seed extracts. Asian J Pharm Clin Res 2013;6:152-7.

38. Pavithr S, Sekar T. Phytochemical profiling, free-radical scavenging and anti-inflammatory activities of Meliosma simplicifolia (L.). Int J Pharm Pharm Sci 2020;12:62-8.

39. Diomande A, Yao K, Sylla Y, Tra BF, Bakayoko A, Kone MW. Pouvoir antioxydant et teneurs en composés phénoliques de deux espèces du genre albertisia: Albertisia cordifolia (Mangenot and J. Miège) Forman et Albertisia scandens (Mangenot and J. Miège) Forman (Menispermaceae). Eur Sci J 2018;14:128.

40. Kumar S, Gupta A, Pandey AK. Calotropis procera root extract has the capability to combat free radical mediated damage. ISRN Pharmacol 2013;2013:8. 